I-Economics: A Research Journal on Islamic Economics

ISSN 2548-5601, e-ISSN 2548-561X

Vol. 5. No 1. Juni 2019

\title{
THE EFFECT OF DISTRIBUTION FUNDS OF ZAKAT INFAQ SHADAQAH, SOCIAL ASSISTANCE EXPENDITURE, AND SUBSIDY EXPENDITURE ON POVERTY IN INDONESIA
}

\author{
Ade Sofyan Mulazid ${ }^{1}$ Nurul Mudhiatil Mufliha \\ UIN Syarif Hidayatullah Jakarta \\ adesofyanmulazid@uinjkt.ac.id, muflihanurul@gmail.com
}

\begin{abstract}
This study aims to analyze the effect of the distribution funds of Zakat Infaq Shadaqah (ZIS), social assistance expenditure and subsidy expenditure on poverty in Indonesia 2013-2017 period. The sample from this study consisted of ZIS data obtained at the National Alms Agency (known as BAZNAS). Then social assistance expenditure and subsidy expenditure and the latest poverty data obtained at the Central Statistics Agency (BPS). In this research, the method used multiple linear regression analysis by testing classical assumptions. The results of this study are according to the results of the $\mathrm{F}$ test that the three independent variables (ZIS, social assistance expenditure and subsidy expenditure) have a simultaneous effect on the dependent variable (poverty) by having a significance value of 0,000 , which means less than 0.05 .Furthermore, it is supported by the results of the T-test that the three independent variables partially have a significant effect on the dependent variable, with a significance value in the ZIS variable was 0,000 . Then, social assistance expenditure was 0.025 . The last, subsidy expenditure was 0,000. It means lower than 0.05.

Keywords: Zakat Infaq Shadaqah (ZIS), Social Assistance Expenditure, Subsidy Expenditure, Poverty

\section{Introduction}

The Indonesian population, the majority are Muslim. Certainly, know about zakat, zakat is the third pillar of Islam. Every Muslim is obliged to pay zakat, and it is also recommended to give Infaq and Shadaqah. In the distribution funds of zakat, Infaq and Shadaqah have been around since the beginning of Islam. However, not through the amil zakat institution but rather giving directly to mustahik, and also giving to people who are trusted to be distributed to mustahik. This is not optimal because the funds distributed can be given to the same person. Even though there are still many other mustahik, so the distribution becomes uneven. Therefore, the existence of this amil zakat institution can be helped in the distribution of ZIS funds. The distribution of zakat funds was also given to eight asnaf, one of them is poor. Then, the amil zakat institution is not only authorized in distribution, but also management, collection and accumulation.
\end{abstract}

Website:http://jurnal.radenfatah.ac.id/index.php/ieconomics 
I-Economics: A Research Journal on Islamic Economics

ISSN 2548-5601, e-ISSN 2548-561X

Vol. 5. No 1. Juni 2019

Table. 1

\begin{tabular}{|c|c|}
\hline Distribution of ZIS funds 2007-2016 period (In rupiah) \\
\hline Period & Distribution \\
\hline 2007 & $14,900,657,271$ \\
\hline 2008 & $9,422,137,014$ \\
\hline 2009 & $17,467,332,246$ \\
\hline 2010 & $30,010,628,410$ \\
\hline 2011 & $43,417,936,160$ \\
\hline 2012 & $45,465,384,247$ \\
\hline 2013 & $50,615,218,917$ \\
\hline 2014 & $69,649,837,874$ \\
\hline 2015 & $74,587,383,638$ \\
\hline 2016 & $80.252,586,455$ \\
\hline
\end{tabular}

Source: BAZNAS Financial Report

Based on table 1, it can be seen that the funds' distribution of zakat, infaq, and Shadaqah in BAZNAS has increased from each year. Except in 2008, it decreased to $9,422,137,014$. Then, when the funds' distribution of zakat, infaq, and Shadaqah is increased, then mustahik income also increases. The expectation that the mustahik will become muzakkiso the mustahik will decrease. One of the reasons for the increase in poverty in Indonesia is the absence of income from labour, the reason being that the person is unemployed or underemployed.

According to Ritonga, poverty is an inadequate living condition experienced by a person or household so that unable to fulfil the needs of life. The minimum basic needs referred to the needs of food, clothing, housing and social needs that are needed by residents or households to fulfil their daily needs adequately. ${ }^{1}$

Factors that can influence poverty are social assistance expenditure, subsidy expenditure, and funds distribution of ZIS by BAZNAS. According to a social assistance governance study, social assistance Expenditure is expenditure in the form of transfers of money, goods, or services provided by the central or regional government to the community in order to protect the public from the possibility of social risks, increasing economic capacity, and community welfare. Social risk referred to is an event that can create a potential for social vulnerability, both of individual, family, group or community. This is the result of social crises, economic crises,

1 Hamonangan Ritonga, Perhitungan Penduduk Miskin, (Jakarta: Badan pusat Statistik, 2003), hal. 242.

Website:http://jurnal.radenfatah.ac.id/index.php/ieconomics 
political crises, natural phenomena and natural disasters which if not given social assistance will get worse and not be able to live in reasonable.

According to Sri Mulyani, some programs are currently the focus of the government. One of which is encouraging full procurement of social spending. The government will undoubtedly continue to strive so that every policy can play a role in reducing poverty and inequality. According to the Head of BPS, Suhariyanto stated that the percentage of the poor in March 2017 was 10.64\%. The decrease was thinner than in September 2016; it was $0.06 \%$ from $10.70 \%$. This condition is relatively slower than in previous periods.

Meanwhile, the number of inequality in March 2017 was 0.393 or lower of 0.001 points compared to last September 2016; it was 0.394. Then Sri Mulyani assessed that the statistics that appeared still described the results that were still balanced. When viewed from the ministry of agencies that do social spending, it can be more effective. So, it can offset this considerable capital expenditure with improvements in the areas of poverty and inequality.

Furthermore, how to free from the poverty gap, instruments that have been made are needed, such as the funds' distribution of ZIS by BAZNAS, Then social assistance expenditure and subsidy expenditure by the central government. The problem of poverty can be overcome by suppressing the funds' distribution of ZIS in Indonesia, social assistance expenditure and subsidy expenditure. Therefore, this researcher wants to know whether these variables can influence poverty and whether there are significant influences or not. Thus, this research becomes essential to be followed up.

\section{Literature review}

\section{Poverty}

According to Basri, poverty is interpreted as a result of the absence of democracy that reflects a power relationship that eliminates the ability of citizens of a country to decide on issues of their concern. So, the majority of the population lacks a means of production (land and technology) and resources ( education, credit, and market access) ${ }^{2}$

Then BAPPENAS defines poverty as a situation of inadequacy that occurs not because of the will of the poor, but because of a situation that cannot be avoided by the power is on it. There are also those argue that poverty is complicated, because it can be interpreted as economic poverty, social culture, psychological, religious, even to politics, so poverty is a situation where a person does not get the opportunity to own assets and rights. ${ }^{3}$

\section{a. Poor category}

\footnotetext{
${ }^{2}$ Faisal Basri, Perekonomian Indonesia: Tantangan dan Harapan Bagi Kebangkitan Ekonomi Indonesia (Jakarta: Erlangga, 2002), hal. 67.

${ }^{3}$ Soekidjo Notoatmodjo, Pengantar Pendidikan Kesehatan dan Ilmmu (Jakarta: BAPPENAS, 1993), hal. 23.
}

Website:http://jurnal.radenfatah.ac.id/index.php/ieconomics 
The Central Statistics Agency (known as BPS) issued a poverty line of 401,220 rupiahs per capita each month in March 2018. This number was an increase of $3.63 \%$ compared to September 2017 of 387,160 rupiahs per capita each month. If drawn further, the poverty line in March 2016 was 354,386 rupiah per capita each month. Indeed, the number is relatively small. However, Bambang explained that for each person. If one of the family an average of 4 peoples the poverty line was around 1.6 million rupiahs. Then households that have expenditures fewer than 1.6 million rupiahs are categorized as the poor.

Then the World Bank defines absolute poverty as living with an income below $\$ 1$ each day and middle poverty for income below $\$ 2$ each day.

\section{b. Government Poverty Reduction Program}

According to the Ministry of Communication and Information regarding the Indonesian cabinet poverty reduction program, one of which is National Team for the Acceleration of Poverty Reduction or Tim Nasional Percepatan Penanggulangan Kemiskinan (TNP2K) is an institution formed to handle and coordinate matters relating to reduction and eradication of poverty in the Republic of Indonesia.

Table 2.

Main Instrument to Poverty Reduction

\begin{tabular}{|c|c|c|}
\hline Cluster I & Cluster II & Cluster III \\
\hline $\begin{array}{c}\text { Program Social } \\
\text { Bastance integrated }\end{array}$ & $\begin{array}{c}\text { Program Poverty } \\
\text { Reduction Based } \\
\text { Community } \\
\text { Empowerment }\end{array}$ & $\begin{array}{c}\text { Program Poverty } \\
\text { Reduction Based on } \\
\text { Micro and Small Business } \\
\text { Empowerment }\end{array}$ \\
\hline $\begin{array}{c}\text { Aim: } \\
\text { Reducing the burden on } \\
\text { poor households through } \\
\text { increasing access to } \\
\text { health, education, clean } \\
\text { water and sanitation } \\
\text { services }\end{array}$ & $\begin{array}{c}\text { Arim: } \\
\text { strengthen the capacity of } \\
\text { groups of poor people to } \\
\text { be involved in } \\
\text { development based on } \\
\text { principles }\end{array}$ & $\begin{array}{c}\text { Aim: } \\
\text { access and strengthening } \\
\text { for micro and small-scale } \\
\text { business actors }\end{array}$ \\
\hline
\end{tabular}

Source: TNP2K (National Team Acceleration of Poverty Reduction)

\section{Zakat, Infaq and Shadaqah (Alms) \\ a. Zakat}

Zakat is the Masdar word from zaka which means blessing, growing, clean, and good. According to Lisan al-Arab, Zakat means holy, growing, blessing and praiseworthy. Then according to Wahidi the word zaka means to increase. ${ }^{4}$ Zakat

${ }^{4}$ Yusuf Qardawi, Hukum Zakat. Terj: Salman Harun, Didin Hafidhuddin, Hasanuddi (Bogor: Pustaka Litera Antar Nusa,1996), hal. 55.

Website:http://jurnal.radenfatah.ac.id/index.php/ieconomics 
regarding the term fiqh means some certain assets that are required and submitted to those who are entitled. Ibnu Taimiah said "The soul of the person who commits Zakat becomes clean and wealth will be clean as well," see Q.S At-Taubah: 103. Besides, the group that has the right to receive zakat can be seen by Q.S. At-Taubah: 60 .

\section{b. Infaq}

Infaq is an additional gift issued by a Muslim capable of part of its wealth, solely to seek the pleasure of Allah SWT. Infaq also means charity, living, giving wealth (other than zakat) for good, such as infaq of the poor Muslims, infaq of natural disasters, infaq of humanity and others. Infaq words are not only used in connotations, but the suggestion to allocate a portion of the acquisition in the way of Allah also uses the word infaq. ${ }^{5}$

According to Subianto, the legal infaq is fardhu kifayah or obligatory for a Muslim community. If there is no one group from the community who works, then all the individuals of that society will sin big. While, if someone has done it, then the sins of other groups of the community fall. However, for members of the community who do not fulfil it, then he becomes a human being who loses and becomes the dumbest man because he does not participate in planting shares or reward. Must be in the congregation, the reward is huge. ${ }^{6}$

\section{c. Sadaqah (Alms)}

The word sadaqah (alms) comes from Arabic "sadaqah." In language means "true or honest." Whereas according to the term, shadaqah means a gift voluntarily, both in the form of money, goods, services, kindness, and others. This is given to the person who has the right to receive it with a number that is not determined, given anytime and anywhere for the sake of hope and reward from Allah SWT. The definition of shadaqah based on the hadith of the Prophet narrated by Imam Bukhari and Muslim. Both of them related that the Prophet said that every Muslim must give sadaqah(alms). ${ }^{7}$

While, according to Ghazaly at the beginning of the growth of Islam, sadaqah was interpreted as a gift that was sunnah. However, after the obligation of sadaqah is given of the Qur'an it is often mentioned the word "sadaqah." Therefore, "sadaqah" has two meanings. First, sunnah "sadaqah", and second is obligatory "shadaqah (zakat)". According to Syara, sadaqah is interpreted as a gift of someone sincerely to the person who has the right to receive a reward from Allah SWT also accompanies that. ${ }^{8}$

\section{Obligations of Zakat in Maqashid Syariah}

According to Ash-Syatibi, maqashid sharia is a human benefit, both in the world and in the hereafter. Then in expression Asy-Syatibi asserted that the prescription of

\footnotetext{
5 Yuke Rahmawati, Lembaga Keuangan Mikro Syariah UIN Jakarta (Jakarta: Press.Banten 2013), hal. 65.

6 Achmad Subianto, Shadaqah Infak dan Zakat Sebagai Instrumen Untuk Membangun Indonesia Yang Bersih Sehat dan Benar (Jakarta: Yayasan Bermula, 2014), hal. 45.

${ }^{7}$ Masykur Arif, Sedekah itu Ajib (Jogjakarta: DIVA Press, 2004), hal. 234.

8 Abdul Rahman Ghazaly, dkk, Fiqh Muamalat, (Jakarta: Kencana, 2010), hal. 45. dalam Abdul Aziz dkk, Kapita Selekta Ekonomi Islam Kontemporer (Bandung: Alfabeta, 2010), hal. 67.
}

Website:http://jurnal.radenfatah.ac.id/index.php/ieconomics 
laws was for the benefit of a servant. Each of taklif syari must have a reference to a maqashid sharia. ${ }^{9}$ Following this, maqashid sharia is classified into three levels:

\section{a. Dhoruriyyat (Necessity)}

Dhoruriyyat is a maqashid that must be there to uphold the problems of goodness in matters of religion and the world. If the maqashid does not exist, the good things of the world will not work. It means, if mashlahah is damaged, the stability of world life will be damaged. Dhoruriyyat in the priority scale is called the primary interest is the basis and foundation of other interests. Examples are prayer, zakat, fasting and pilgrimage. The main points of worship refer to hifdz al-din include faith, two confessions of faith, prayer, zakat, fasting, pilgrimage, and so on. Dhoruriyyat is divided into five, namely: hifdz al-din (guarding religion), hifdz al-nafs (guarding the soul), hifdz nasal (guarding offspring), hifdz maal (guarding wealth) and hifdz aql (guarding intellectuals).

\section{b. Hajjyat (Needs)}

Hajiyyat is maqashid is based on freedom and eliminates the narrowness that is in the habit. Example: ruhshah of prayer, qiradh (to pay money) and others. In the scale priority of hajiyyat is referred to as a secondary interest which becomes a buffer and perfects the primary interests.

\section{c. Tahsiniyyat (decking)}

Tahsiniyyat is a maqashid is taken and based on considered, both of ritual and keeping things considered despicable according to common sense. Examples, a ritual in eating and drinking, avoid excessive eating. If in the muammalah field, for examples the prohibition on selling unclean goods. In the priority scale tahsiniyyat called tertiary interest as an element that is complementary to the support of secondary importance.

In these three shari'a maqashids is required namely the need for charity is the level of need that must exist because this maqashid cannot be avoided in sustaining the masses of al-din (hereafter) and the world. If this maslahah is destroyed, then the life of the world will be damaged, and the destruction of this maslahah results at the end of life in the world and the hereafter. It also revealed the loss of safety and grace. This example of dhoruriyyat is one of them in hifdz al-din (zakat).

\section{Social Assistance Expenditure}

According to JDIH (Legal Information and Documentation Network) of the Ministry of Finance, Social Assistance Expenditures are expenditures in the form of transfers of money, goods or services provided by the Central or Regional Government to the public in order to protect the public from the possibility of social risks. This is intended to improve the economic capacity or welfare of the community. Social risk is an event that can cause the potential for social vulnerability to be borne by individuals,

${ }^{9}$ Asy-Syatibi. al-Muwāfaqāt fi Ușūl asy-Syarī'ah, Beirut: Daral-Kutub (Surabaya: Pustaka Progresif, 1997), hal. 88.

Website:http://jurnal.radenfatah.ac.id/index.php/ieconomics 
families, groups, and communities. This social risk is as a result of social crises, economic crises, political crises, natural phenomena, and natural disasters which if not given Social Assistance Expenditures will get worse and cannot live in fair conditions. Expenditures for social assistance are given in the form of money, goods and services. Shopping for social assistance is temporary or sustainable in order to provide social rehabilitation, social protection, social security, social empowerment and poverty reduction in order to improve the level of welfare, quality of survival, and restore social functions in order to achieve independence.

\section{Subsidy Expenditure}

According to the Government Accounting Standards Committee (KSAP), subsidy expenditure is a government budget allocated to manufacturers with the aim of helping production costs so that selling prices are affordable to the public. This budget is mainly for "Public Service Obligations" whose selling prices are intervened by the government. According to BPS, in subsidies include all assistance in the form of money or goods provided by the government to private companies and government companies. Subsidies in the form of goods are subsidies for goods that are used up in one production process so that assistance in the form of capital goods and the form of money for capital formation is not included. The purpose of subsidies among others is to maintain price stability, cover losses suffered by the company and others. The data included in the details of these subsidies are fuel subsidies and fertilizer subsidies.

\section{Research Methods}

This research was focused on testing hypotheses, measuring the variables being studied and will produce conclusions, and using statistical tools. To answer the problem statement and test the hypothesis, there are several variables used consisting of three variables. The poverty level is a dependent variable. While, for independent variables or independent variables are the ZIS distribution in BAZNAS, social assistance expenditure and subsidy expenditure on the realization of government expenditure.

In this study, the steps that must be done first, namely by using the Classical Assumption Test, then use the model statistics to test Multiple Linear Regression and Statistical Tests in this study using Time Series data and using the SPSS application.

\section{Analysis of Results and Discussions}

\section{Classic assumption test}

This test was conducted to detect the presence or absence of multicollinearity, autocorrelation, heteroscedasticity and normality. Then this classic assumption test is carried out before analyzing the linear regression model, and if there is a deviation from the classic assumption of the F-test and the t-test carried out becomes invalid, and statistically, it will not get a reasonable conclusion.

\section{a. Multicollinearity Test}

Website:http://jurnal.radenfatah.ac.id/index.php/ieconomics 
If the Tolerance (Tol) value $<0.1$, then the regression model has multicollinearity. If the value of the Variance Inflation Factor (VIF)> 10, then the regression model has multicollinearity. ${ }^{10}$

Table 3.

Multicollinearity Test

\begin{tabular}{|c|c|c|c|c|}
\hline Free variable & $\begin{array}{c}\text { Tolerance } \\
\text { value }\end{array}$ & $\begin{array}{c}\text { Value } \\
\text { VIF }\end{array}$ & $\begin{array}{c}\text { Results } \\
\text { Interpretation }\end{array}$ & Information \\
\hline ZIS & 0.891 & 1,122 & $\begin{array}{c}\text { Tolerance value }> \\
0.1 \\
\text { VIF value }<10\end{array}$ & $\begin{array}{c}\text { There is } \\
\text { nomulticollinearity }\end{array}$ \\
\hline $\begin{array}{c}\text { Social Assistance } \\
\text { Expenditure }\end{array}$ & 0,150 & 6,674 & $\begin{array}{c}\text { Tolerance value }> \\
0.1 \\
\text { VIF value }<10\end{array}$ & $\begin{array}{c}\text { There is no } \\
\text { multicollinearity }\end{array}$ \\
\hline SubsidyExpenditure & 0.149 & 6,731 & $\begin{array}{c}\text { Tolerance value }> \\
0.1 \\
\text { VIF value }<10\end{array}$ & $\begin{array}{c}\text { There is no } \\
\text { multicollinearity }\end{array}$ \\
\hline
\end{tabular}

Based on table 3, Value Tolerance in a variable of ZIS was 0.891, Social Assistance was 0.150, and Subsidy was 0.149. All the independent variables there is no multicollinearity because the Tolerance value $>0.1$. Furthermore, based the VIF values for variable ZIS was 1,222, Social Assistance was 6,674 and Subsidy was 6,731. All of the independent variables there is multicollinearity because of the VIF value $<10$.

\section{b. Autocorrelation Test}

In this study using the method of Durbin Watson, according to Santoso cited in the Haryoseto said that there are some criteria in concluding whether the presence or absence autocorrelation as follows:

If the DW value is below -2, it means positive autocorrelation

If the DW value between -2 to 2 means there is no autocorrelation

If the DW value is above 2 , it means negative autocorrelation

Table 4

Autocorrelation Test

\begin{tabular}{|c|c|c|c|}
\hline $\begin{array}{c}\text { Durbin } \\
\text { Watson } \\
\text { Value }\end{array}$ & $\begin{array}{c}\text { Free } \\
\text { Autocorrelation } \\
\text { Limit }\end{array}$ & $\begin{array}{c}\text { Results } \\
\text { Interpretation }\end{array}$ & Information \\
\hline 0,672 & -2 to +2 & $\begin{array}{c}\text { Between }-2 \\
\text { and }+2\end{array}$ & $\begin{array}{c}\text { There is no } \\
\text { autocorrelation }\end{array}$ \\
\hline
\end{tabular}

10 D.N. Gujarati, Basic Econometrics, 4th Edition, (New York: United State Military Academy,1995), hal. 71.

Website:http://jurnal.radenfatah.ac.id/index.php/ieconomics 
Based on the results of the data in table 4 above, According to Santoso there is no symptom of autocorrelation because Durbin Watson value is equal to 0.672. It means the symptoms of DW autocorrelation between -2 to $+2 .{ }^{11}$

\section{c. Heteroscedasticity Test}

According to Suliyanto to detect the presence or absence of heteroscedasticity, it can be done by graph analysis by observing the scatterplot where the horizontal axis describes Predicted Standardized. While the vertical axis describesthe value of Residual Studentize, then if the Scatterplot spreads randomly, and the points spread above and below the number zero ( 0$)$ on the $\mathrm{Y}$ axis, there is no heteroscedasticity.

\section{Graph 1. Scatterplot Heteroscedasticity Test}

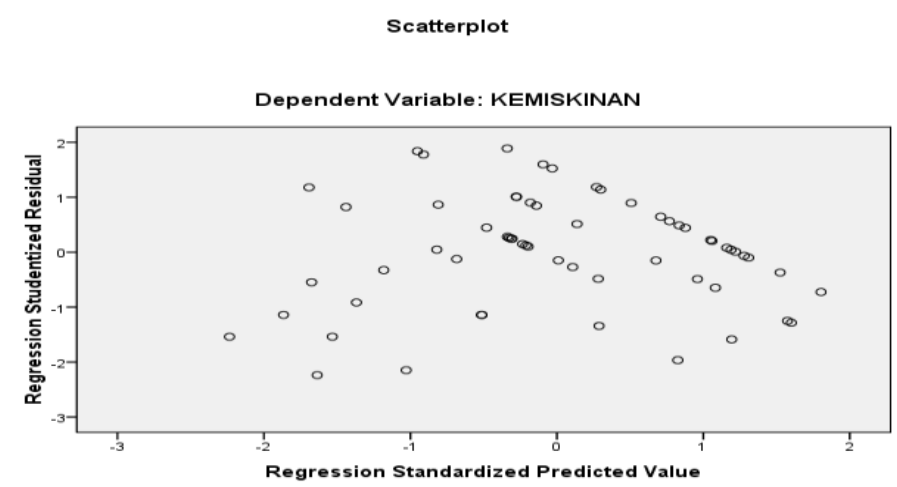

\section{d. Normality test}

According to Suliyanto, this can be detected by histogram graph analysis by describing the dependent variable as the vertical axis while the standardized residual value is described as the horizontal axis. If the Standardized Regression Residual Histogram forms a bell-like curve, the residual value is normal. Then another way to test normality by looking at the results of the Normal P-Plot chart:

If the points are close to the diagonal line, it means fulfilling the normality assumption

If the points stay away from the diagonal line it means that there is no normality assumption.

\section{Graph 2.}

\section{Histogram Normality Test}

${ }^{11}$ Singgih Santoso, Statistik Parametik (Jakarta: PT Gramedia Pustaka, 2012), hal. 54.

Website:http://jurnal.radenfatah.ac.id/index.php/ieconomics 


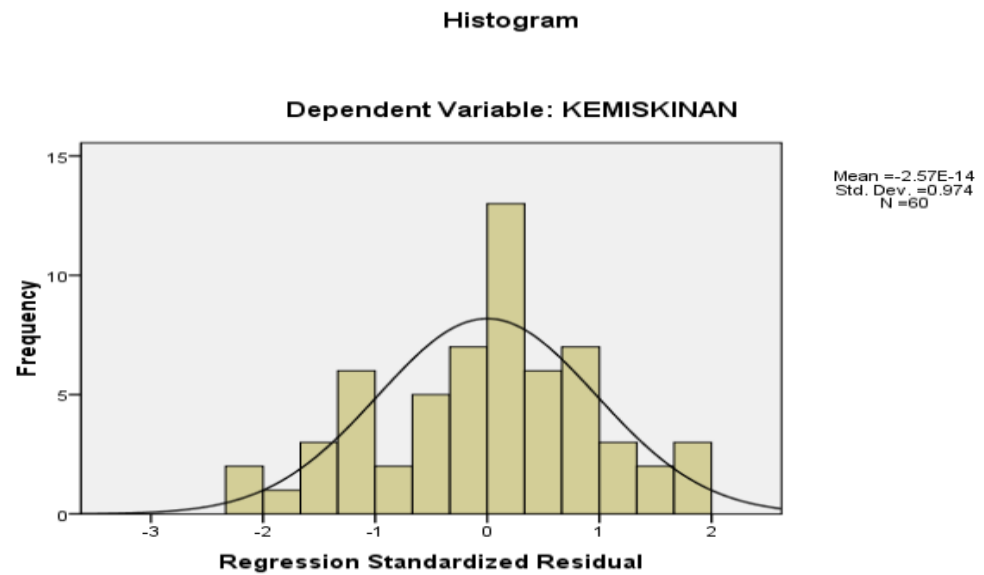

Based on the results of the normality test, it can be seen the display on the histogram graph which is concluded that the histogram graph tends to form a normal convex curve with a standard deviation number approaching one, it is equal to 0.974 .

\section{Graph 3.}

\section{P-Plot Normality Test}

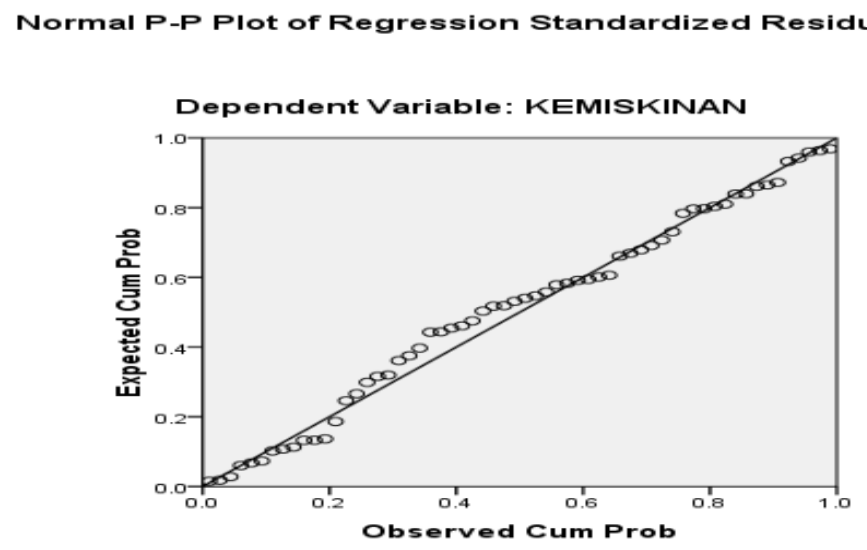

Based on the results of the graph in above, it can be seen the normal P-Plot graph display it can be concluded that the distribution pattern with scattered points narrows around the diagonal and both of these indicate that the residuals are normally distributed.

\section{Multiple Linear Regression Analysis}

Regression analysis is used to estimate or predict the average value of the dependent variable based on the value of the known independent variables. The results of data management obtained using the SPSS program.

Website:http://jurnal.radenfatah.ac.id/index.php/ieconomics 
I-Economics: A Research Journal on Islamic Economics

ISSN 2548-5601, e-ISSN 2548-561X

Vol. 5. No 1. Juni 2019

Table 4.

Results of Multiple linear Regress Analysis

\begin{tabular}{|c|c|c|c|c|c|}
\hline \multirow{2}{*}{ Model } & \multicolumn{2}{|c|}{$\begin{array}{c}\text { Unstandardized } \\
\text { Coefficients }\end{array}$} & $\begin{array}{c}\text { Standardized } \\
\text { Coefficients }\end{array}$ & \multirow{2}{*}{ T } & \multirow{2}{*}{ Sig } \\
\cline { 2 - 5 } & $\mathbf{B}$ & Std.Error & Beta & & \\
\hline (Constant) & $\mathbf{2 . 8 8 1}$ & .380 & & 7,591 & .000 \\
\hline ZIS & $\mathbf{- . 0 1 6}$ & .003 & -400 & $-4,633$ & .000 \\
\hline $\begin{array}{c}\text { Social } \\
\text { Assistance }\end{array}$ & $\mathbf{. 0 3 8}$ & .15 & .546 & 2.496 & .16 \\
\hline Subsidy & $\mathbf{- . 0 1 1}$ & .002 & -1.004 & $-4,573$ & .000 \\
\hline
\end{tabular}

The multiple linear regression equation models for this study were:

$$
\begin{gathered}
Y=a+b 1 X 1+b 2 X 2+b 3 X 3+e \\
\mathrm{Y}=2.881+(-0,016) \mathrm{X} 1+0,038 \mathrm{X} 2+(-0,011) \mathrm{X} 3
\end{gathered}
$$

Noted:

$$
\begin{aligned}
& \mathrm{Y}=\text { Poverty } \\
& \mathrm{a}=\text { Constant } \\
& \mathrm{b}=\text { Regression Coefficient } \\
& \mathrm{X} 1=\text { ZIS } \\
& \mathrm{X} 2=\text { Social Assistance } \\
& \mathrm{X} 3=\text { Subsidy } \\
& \mathrm{e}=\text { Error term, assumed to be } 0
\end{aligned}
$$

Regression equation in above can be explained as follows:

The value of the Constant was 2.881. It means that if ZIS (X1) Social Assistance (X2) and Subsidy (X3) value 0, and then poverty (Y) value was 2.881 .

The regression coefficient of the ZIS (X1) variable was -0.016. It means that if the independent variable is fixed and ZIS has a $1 \%$ increase, then poverty (Y) will decrease 0.016. The coefficient is negative. So, it can be concluded there is a negative relationship between ZIS and poverty, the higher value of ZIS, the more poverty decreases.

The regression coefficient of Social Assistance (X2) variable was 0.038. It means that if the independent variable is fixed and Social Assistance increases by $1 \%$, then poverty (Y) will increase of 0.038 . The coefficient is positive, It means there is a positive relationship between Social Assistance and poverty, the higher the value of the Social Assistance, the more poverty increases.

The regression coefficient of Subsidy (X2) variable was -0,011. It means that if the independent variable is fixed and the Subsidy was a $1 \%$ increase, then poverty (Y)

Website:http://jurnal.radenfatah.ac.id/index.php/ieconomics 
will decrease of 0.011 . The coefficient is negative; it means there is a negative relationship between subsidy and poverty, the higher the value of the subsidy, the lower the poverty.

\section{a. Determination Coefficient Analysis}

The coefficient of determination (adjusted R2) essentially measures how far the model's ability to explain the variation of the dependent variable. The adjusted $\mathrm{R} 2$ value that approaches one (1) it means the ability of the independent variables to provide almost all the information needed to predict variations in the dependent variable.

\section{Table 5.}

\section{The coefficient of Determination (adjusted R2)}

\begin{tabular}{|c|}
\hline Adjusted R Square \\
\hline 0.577 \\
\hline
\end{tabular}

Based on the results of research on the table above, it shows that the coefficient of determination (adjusted R2) was obtained of 0.607 or $60.7 \%$. It means that $57.7 \%$ of poverty can be influenced and explained by independent variables in the form of ZIS, Social Assistance, and Subsidy. Other variables explained Whiles, the remaining of $42.3 \%$.

\section{b. F-Statistic Test Analysis (Simultaneous Test)}

The F-statistical test shows whether all the independent variables included in the model have a joint effect on the dependent variable. Assumptions used in making decisions on the F-test based on:

Comparison of F-Count and F-Table

$\checkmark$ If F-Calculate $>\mathrm{F} \alpha(\mathrm{k}, \mathrm{n}-\mathrm{k}-1)$ then $\mathrm{H} 0$ is rejected

$\checkmark$ If F-Calculate $<\mathrm{F} \alpha(\mathrm{k}, \mathrm{n}-\mathrm{k}-1)$ then $\mathrm{H} 0$ is accepted

Probability

$\checkmark$ If the Prob (P-value) > Significance level, then H0 is accepted

$\checkmark$ If the Prob (P-value) <Significance level then $\mathrm{H} 0$ is rejected

Table 6.

Test F Statistic (Simultaneous test)

\begin{tabular}{|c|c|}
\hline $\mathbf{F}$ & Sig \\
\hline 27,838 & .000 \\
\hline
\end{tabular}

From the results of testing the simultaneous significance in the table above, it can be seen that the independent variable has a significance F-count of 27,838, it means the value is higher than the F- table value of 2.790 . Then, it can also be seen at the significance of 0,000 . It means the value is lower than the significance level of $5 \%$ or 0.05. So, $\mathrm{H} 1$ is accepted, and then the regression model can be used to predict poverty, or note that independent variables (ZIS, Social Assistance, and subsidy) simultaneously influence poverty.

\section{c. Analysis of the T-Statistic Test (Partial Test)}

Website:http://jurnal.radenfatah.ac.id/index.php/ieconomics 
The T-statistical test shows how far the effect of one independent variable individually in explaining the variation of the dependent variable. A variable will have a meaningful effect if the T-count value of the variable is higher than the value of the T-table. The assumptions used in decision making were:

Comparison of T-Count and T-Table

$\checkmark$ If T-Count $>\mathrm{T}$-Table then $\mathrm{H} 0$ is rejected

$\checkmark$ If T-Count <T-Table then HO is accepted Probability

$\checkmark$ If the Prob (P-value) > Significance level, then H0 is accepted

$\checkmark \quad$ If the Prob (P-value) <Significance level then H0 is rejected

Table 7.

T-Statistic Test (Partial Test)

\begin{tabular}{|c|c|c|}
\hline Model & T & Sig \\
\hline (Constant) & 7,591 & .000 \\
\hline ZIS & $-4,633$ & .000 \\
\hline Social Assistance & 2.496 & .16 \\
\hline Subsidy & $-4,573$ & .000 \\
\hline
\end{tabular}

Based on the results of the t-test on the table calculated using SPSS, the following decisions can be:

a) Testing of the ZIS variable

ZIS has a significance value of $0,000<0.05$ significance level. It means $\mathrm{H} 1$ is accepted so that the ZIS variable has a significant effect on poverty.

b) Testing of Social Assistance variables

Social Assistance has a significance value of $0.016<0.05$ significance level. It means $\mathrm{H} 2$ is accepted so that Social Assistance variable has a significant effect on poverty.

c) Testing of Subsidy variables

The subsidy has a significance value of $0,000<0.05$ significance level. It means H3 is accepted so that the Subsidy variable has a significant effect on poverty.

\section{Discussions}

\section{The Effect of ZIS Partially on Poverty in Indonesia}

The effect of ZIS partially on poverty in Indonesia based on the t-test states that ZIS partially affects poverty in Indonesia in January 2013 to December 2017 period. This can be proven from the results of the t-test is equal to $-4,633$ and has a significance value of $0,000<$ level significance of 0.05 . So, it can be concluded that this ZIS variable has a significant effect on poverty.

\section{The Effect of Social AssistancePartially on Poverty in Indonesia}

Website:http://jurnal.radenfatah.ac.id/index.php/ieconomics 
I-Economics: A Research Journal on Islamic Economics ISSN 2548-5601, e-ISSN 2548-561X

Vol. 5. No 1. Juni 2019

The effect of Social Assistance partially on poverty in Indonesia based on the ttest states that social assistance partially effects on poverty in Indonesia in January 2013 to 2017 period. From this study, it can prove from the results of the t-test of 2.496 and have a significance of 0.016 <ignificance level of 0,05 . So, it can be concluded that this social assistance has a significant effect on poverty.

\section{The effect of subsidy partially on poverty in Indonesia}

The effect of subsidies partially on poverty in Indonesia based on the t-test states that subsidy partially affects poverty in Indonesia in January 2013 to December 2017 period. It can be proven from the results of the t-test is equal to $-4,573$ and has a significance value of $0,000<$ level significance of 0.05 . Then it can be said that this Subsidy variable has a significant effect on poverty.

\section{The Effect of ZIS Funds, Social Assistance, and Subsidy Distribution Simultaneously Influences Poverty in Indonesia}

Based on the results of research from all independent variables, namely ZIS, Social Assistance, and Subsidy, there is a significant simultaneous effect on poverty in Indonesia in January 2013 to December 2017 period. It can be proved with the f-test results of the significance value was 0,000 . According to Suliyanto if the significance value was $<\alpha$ of 0.05 , then this result can be concluded that the independent variables are simultaneous can explain changes in the dependent variable (variable bound). ${ }^{12}$

From this result, we can find out that the effect of ZIS funding, Social Assistance and Subsidy has a simultaneous effect on poverty, this is supported by a ttest which results as a whole in the independent variable have a significant and partial effect on poverty. It can be seen from the significance value of the ZIS variable was 0,000 then Social Assistance was 0.016, and the last, Subsidy was 0,000.

\section{Conclusions}

Based on this research, the conclusions can be drawn from the results of the analysis and discussion as follows:

1. The funds' distribution of ZIS (Zakat, Infaq, and sadaqah) in BAZNAS has a significant effect on poverty in Indonesia in January 2013 to 2017 period with a significance value of 0,000 .

2. The Social Assistance Expenditures has a significant effect on poverty in Indonesia in January 2013 to 2017 period with a significance value of 0.016 .

3. The Subsidy Expenditures has a significant effect on poverty in Indonesia in January 2013 to 2017 period with a significance value of 0,000 .

4. The funds' distribution of ZIS, Social Assistance Expenditures and Subsidy Expenditures have a simultaneous effect on poverty in Indonesia in January 2013 to 2017 period with a significance value of 0,000 .

12 Suliyanto, Ekonometrika Terapan : Teori dan Aplikasi dengan SPSS (Jakarta: Andi Publisher, 2011), hal. 65.

Website:http://jurnal.radenfatah.ac.id/index.php/ieconomics 
I-Economics: A Research Journal on Islamic Economics

ISSN 2548-5601, e-ISSN 2548-561X

Vol. 5. No 1. Juni 2019

\section{References}

Abdul, Rahman, Ghufron dan Sapiudin. "Fiqh Muammalat”. Prenadamedia Group. Jakarta. 2010.

BAZIS. "Mengenal Hukum Zakat, Infak dan Sedekah”

Basri, Faisal."Perekonomian Indonesia: Tantangan dan Harapan Bagi Kebangkitan Ekonomi Indonesia”. Erlangga. Jakarta. 2002.

Arif, Masykur, “Sedekah itu Ajib”. DIVA Press. Jogjakarta. 2004.

Qardawi, Yusuf. "Hukum Zakat. Terj: Salman Harun, Didin Hafidhuddin, Hasanuddin”. Pustaka Litera Antar Nusa. Bogor. 1996.

Rahmawati, Yuke. “Lembaga Keuangan Mikro Syariah”. UIN Jakarta Press.Banten 2013.

Ritonga, Hamonangan. 2003. Perhitungan Penduduk Miskin. Jakarta: Badan pusat Statistik.

Subianto, Achmad."Shadaqah Infak dan Zakat Sebagai Instrumen Untuk Membangun Indonesia Yang Bersih Sehat dan Benar". Yayasan Bermula dari Kanan. 2014.

Suliyanto. “Ekonometrika Terapan” : Teori dan Aplikasi dengan SPSS”. Andi.

Tulus T.H, Tambunan, “Perekonomian Idonesia”. Ghalia Indonesia. Jakarta. 2014.

\section{Sumber Internet}

https://Pusat Baznas.go.id diakses 8 November 2017

http://repository.unair.ac.id/55719/13/FEB.EI.\%20140-16\%20Set\%20p-min.pdf diakses 10 November 2017

http://repository.ipb.ac.id/bitstream/handle/123456789/55311/2012sdp.pdf?sequence $=1 \&$ isAllowed $=\mathrm{y}$ diakses 10 November 2017

https://web.kominfo.go.id/sites/default/files/ProgramPenanggulanganKemiskinan Kabinet Indonesia BersatuII.pdf diakses 5 Desember 2017

http://www.anggaran.depkeu.go.id/content/Publikasi/Kajiandanartikel/KajianTata Kelola Bansos.pdf diakses 15 Desember 2017

https://tirto.id/menkeu-dorong-belanja-sosial-untuk-kurangi-angka-kemiskinan-csXW diakses 8 Januari 2018

Website:http://jurnal.radenfatah.ac.id/index.php/ieconomics 
I-Economics: A Research Journal on Islamic Economics ISSN 2548-5601, e-ISSN 2548-561X

Vol. 5. No 1. Juni 2019

http://ksp.go.id/subsidi-dan-bantuan-sosial-dalam-apbn-harus-efektif-mengurangikemiskinan/ diakses 10 Desember 2017

http://www.sjdih.depkeu.go.id/fullText/2012/81 PMK.05 2012Per.HTM diakses 9 februari 2018

http://bapsi.unri.ac.id/855/ diakses 10 Januari 2018

http://www.hukumprodeo.com/bantuan-sosial-bansos-yang-berasal-dari-anggaranpendapatan-dan-belanja-daerah/ diakses 7 Maret 2018

https://www.ksap.org/sap/beda-belanja-subsidi-bantuan-sosial-dan-hibah/ diakses 8 Maret 2018

http://www.jdih.kemenkeu.go.id/fullText/2011/101 PMK.02 2011PerLamp\%20III.h tm diakses 12 Maret 2018

https://sirusa.bps.go.id/index.php?r=istilah/view\&id=2282 diakses 23 April 2018

http://www.dpr.go.id/doksetjen/dokumen/apbn_Dimensi_Kemiskinan201301301358

44.pdf diakses 2 oktober 2018

Website:http://jurnal.radenfatah.ac.id/index.php/ieconomics 